\title{
MODERN EXTRAORDINARY STEEL STRUCTURES IN GERMANY
}

Prof. Dr.-Ing. habil. Hartmut Pasternak ${ }^{1}$

UDK 624.014.2 : 725.391(430.131)

DOI: $10.14415 /$ konferencijaGFS2021.61

A large hangar for airships was built 80km outside of Berlin in 1999/2000. The hangar that was initially built for the CargoLifter is an arched construction with a height of $108 \mathrm{~m}$ and a span of 200m. In 2005 it was then transformed into a tropical holiday resort (Fig. 1).

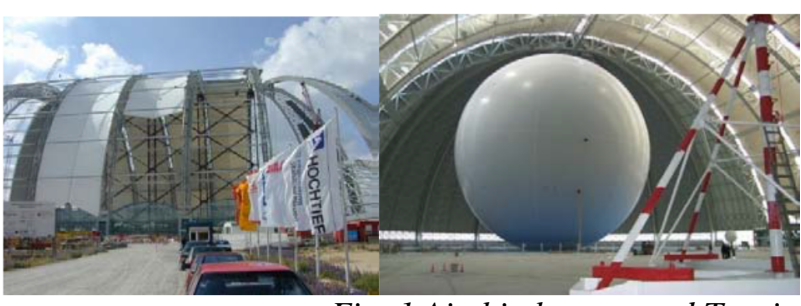

Fig. 1 Airship hangar and Tropical Island

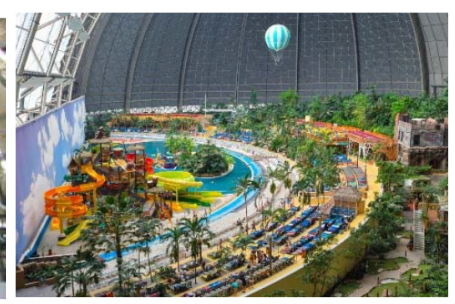

The main train station was built in the center of Berlin. In 2005/06. The station hall has the span of $66 \mathrm{~m}$ and a height of $16 \mathrm{~m}$. It is fully in steel and glass. Four $50 \mathrm{~m}$ towers were erected next to the station hall, which were then joined together to form two parallel structures above the station hall (Fig. 2).

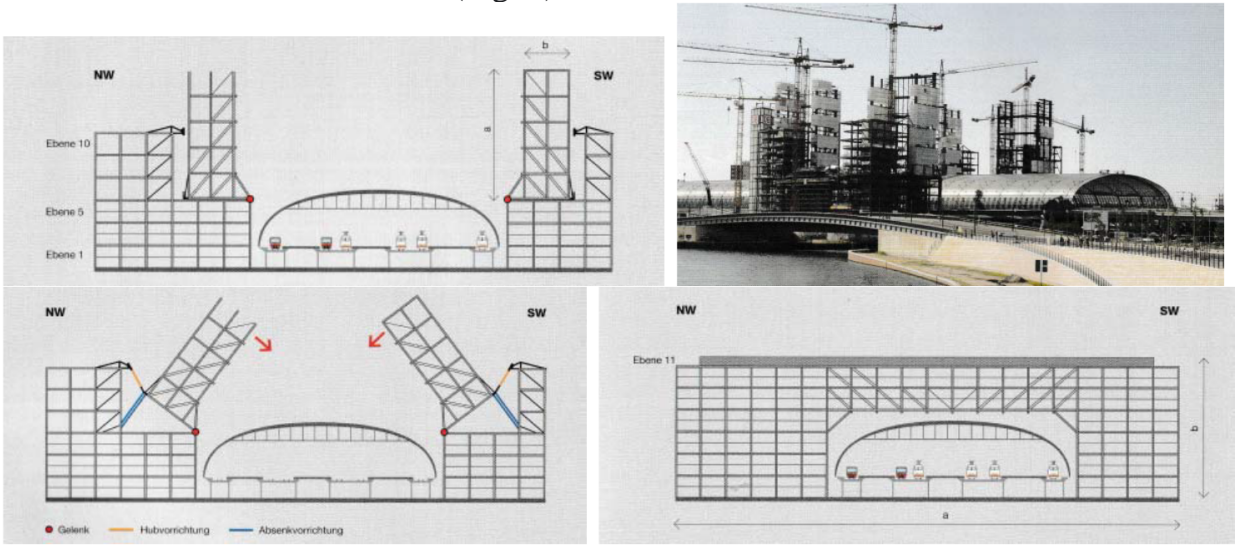

Fig. 2 Folding down the bow bridges of the main train station

The next example is a small-scale measure: a school in Wolfsburg, which was built in reinforced concrete at the 1970ies. The renovation included cutting out the ceilings and making space for a light-flooded cafeteria. Steel and glass were used (Fig.3).

\footnotetext{
${ }^{1}$ Prof. Dr.-Ing. habil. Hartmut Pasternak, BTU, Cottbus, Germany
} 
8.

МЕЂУНАРОДНА КОНФЕРЕНЦИЈА

Савремена достигнућа у грађевинарству 22-23. април 2021. Суботица, СРБИЈА
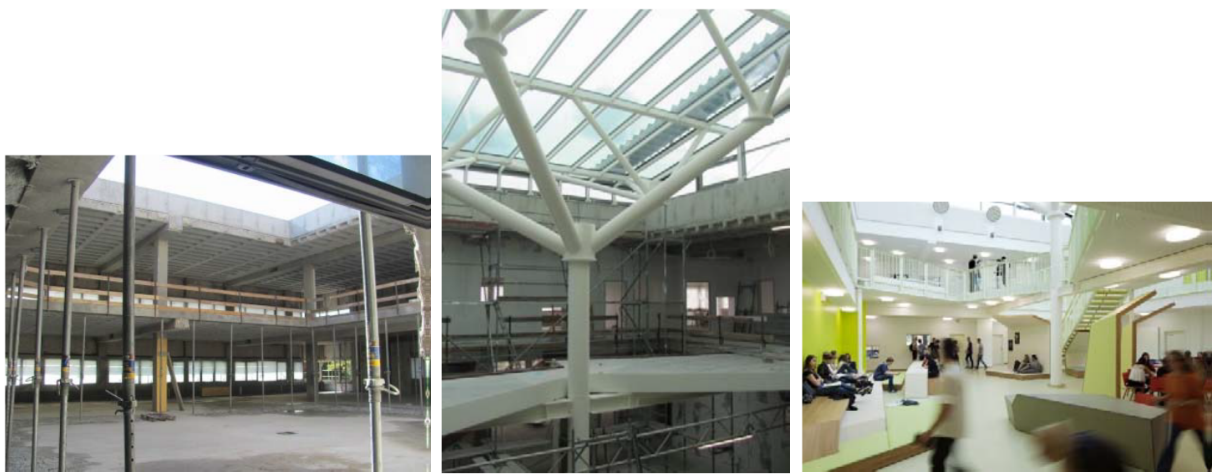

Fig. 3 Cafeteria in a school building

In 2012 a new attraction was open in the Autostadt Wolfsburg: the Porsche Exhibition Center. As an extension of a laguna, an additional building was executed (Fig.4). The roof of that building is quite interesting: a double-curved, irregular, two-layer shell, a so-called monocoque. This monocoque, made from stainless steel, was carried out by ship builders.
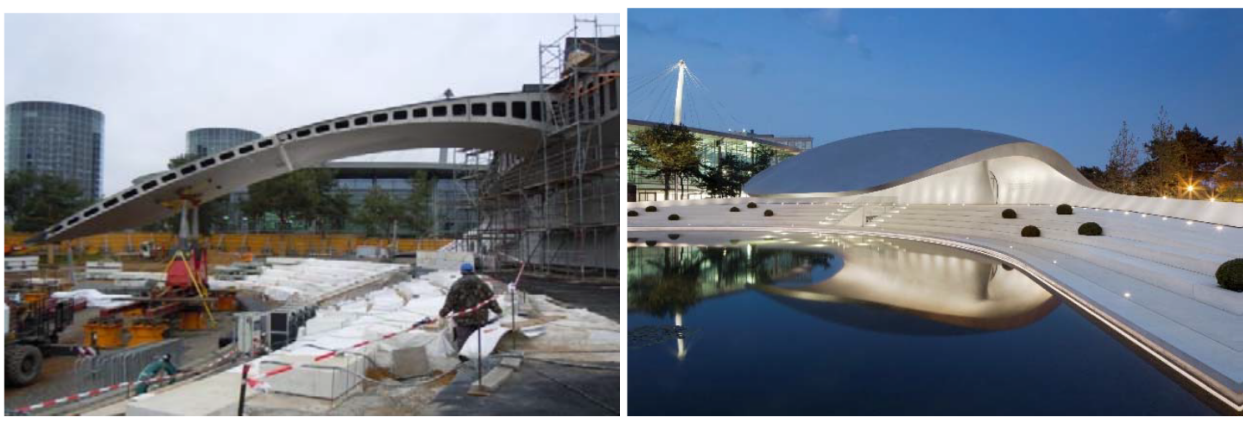

Fig. 4 The Porsche Pavillon

The open roof structure of the Schierker Feuerstein Arena in the northern Part of Germany not only offers protection against sun, snow and rain, but also adds a fascinating room to the unspoilt natural environment. Despite high snow loads of the popular winter sports region, the lightweight, cable supported membrane roof is mounted on two supports only, covering about $2300 \mathrm{~m}^{2}$ in a spectacular gesture (Fig.5).
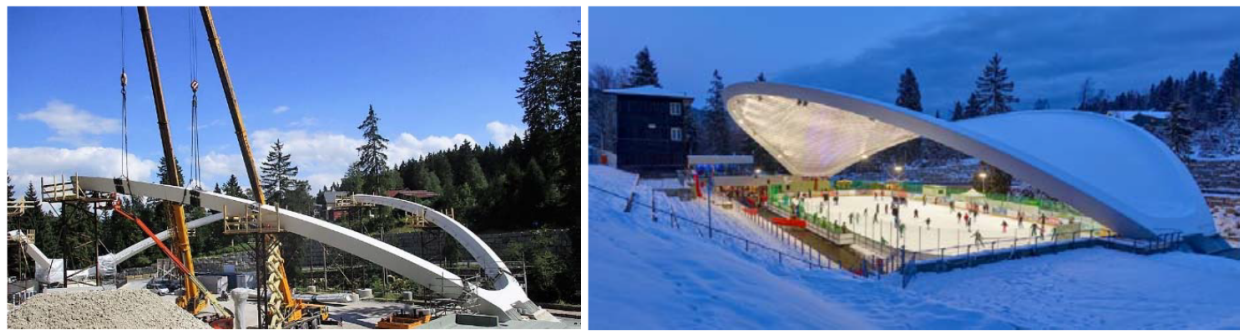

Fig.5 The Feuerstein-Arena in Harz Mountains 